\title{
FAKTOR YANG BERHUBUNGAN DENGAN IBU POST SC DALAM MENYUSUI BAYINYA DI RUANG MAWAR RSUD. Dr. H. SOEWONDO KENDAL
}

Ahmaniyah, Program Studi DIII Kebidanan Universitas Wiraraja

e-mail: ahmaniyah@gmail.com

Iva Gamar Dian Pratiwi, Program Studi DIII Kebidanan Universitas Wiraraja

e-mail: kura_15587@yahoo.com

\section{ABSTRAK}

Menyusui merupakan proses yang fisiologis untuk memberikan nutrisi kepada bayi secara optimal. Pemberian ASI ekslusif sudah diatur oleh peraturan Pemerintah Republik Indonesia no.33 tahun 2012. pengeluaran ASI pada ibu post partum normal lebih cepat dari pada post SC, Beberapa faktor yang mempengaruhi pengeluaran ASI pasca bersalin, yaitu stres setelah persalinan, nyeri, anastesi, melihat, mencium dan mendengar suara tangisan bayi.

pada penelitian untuk mengetahui faktor yang berhubungan dengan prilaku ibu post SC dalam menyusui bayinya. penelitian ini penelitian kuantitatif dengan pendekatan cross sectional

Responden pada penelitian ini berusia $<35$ tahu $(60 \%)$, pendidikan SMP sebanyak $(40 \%)$ dan pekerjaan responden ibu rumah tangga $(86,7 \%)$. Dan faktor yang paling dominan yang dapat mempengaruhi prilaku menyusui pada ibu Post Sc adalah ibu takut gerak atau takut jahitannya lepas. $\mathrm{P}$ value $=0,019$ ( $\mathrm{P}$ value $<0,05$ ) yang maknanya ada hubungan antara faktor - faktor (rasa sakit/nyeri payudara, puting susu pecah, merasa lelah, ASI tidak keluar dan takut gerak/takut jahitan lepas) dengan prilaku inu post partum SC.

faktor rasa sakit/nyeri payudara, puting susu pecah, merasa lelah, ASI tidak keluar dan takut gerak/takut jahitan lepas merupakan faktor yang mepunyai hubungan terhadap prilaku ibu Post SC dalam memberikan ASI secara dini pada bayinya

\section{Kata kunci : Sectio Ceasarea, ASI, Prilaku}

\section{PENDAHULUAN}

Menyusui merupakan proses yang fisiologis untuk memberikan nutrisi kepada bayi secara optimal. Tidak ada hal yang lebih bernilai dalam kehidupan seorang anak selain memperoleh nutrisi yang berkualitas sejak awal kehidupannya. Air susu ibu merupakan nutrisi ideal untuk menunjang kesehatan, pertumbuhan dan perkembangan bayi secara optimal. Pemberian Air Susu lbu (ASI) atau menyusui bayi ini dilakukan di berbagai lapisan masyarakat diseluruh dunia, karena air susu ibu adalah nutrisi terbaik dan terlengkap dibandingkan susu formula serta banyak manfaat yang diperoleh dari Air susu ibu.ASI mengandung lemak, protein, dan air dalam jumlah yang tepat untuk pencernaan, perkembangan otak, dan pertumbuhan bayi. Kandungan nutrisinya yang unik menyebabkan ASI memiliki keunggulan yang tidak dapat ditiru oleh susu formula apapun

Data dari RISKESDAS tahun 2010 presentasi pemberian ASI dalam 1 jam pertama sebesar $29,3 \%$ dan mengalami peningkatan pada tahun 2013 sebesar $34,5 \%$.(RI, 2013) Data ini menunjukkan Peningkatan tetapi jika dibandingkan dengan negara serumpun Asia Tenggara indonesia kalah dibandingkan dengan Bangladesh, vietnam dan Philipina.(Asia, International Baby Food Action Network Asia Unnual Report 2010) Pemberian ASI ekslusif sudah diatur oleh peraturan Pemerintah Republik Indonesia no.33 tahun 2012,(No.33, 2012) dari peraturan ini harus diterapkan pada setiap ibu yang bersalin baik secara pervaginam maupun sectio secarea. Beberapa penelitian menyebutkan bahwa pengeluaran ASI pada ibu post partum normal lebih cepat dari pada post SC.(Desmawati, 2013; Kause, Trisetiyaningsih, \& Sukmawati, 2016) merupakan kendala ibu dalam pemberian ASI. Beberapa faktor yang mempengaruhi pengeluaran ASI pasca bersalin, yaitu stres setelah persalinan, nyeri, anastesi, melihat, mencium dan mendengar suara tangisan bayi. faktor nyeri, ketidak nyamanandan efek anestesi merupakan faktor yang menghambat proses menyusui ibu post SC.(Desmawati, 2013) Di RS Soewondo Kendal di ruang Mawar dari 10 ibu yang bersalin dengan metode SC 80\% Tidak menyusui bayinya, dari kondisi ini perlu diteliti tentang faktor prilaku yang mempengaruhi ibu post SC tidak menyusui bayinya. 


\section{METODE PENELITIAN}

Desain penelitian yang digunakan kuantitatif dengan pendekatan cross sectional, mengggunakan lembar kuesioner. Variabel dependennya adalah prilaku ibu post SC menyusui dan variabel independent adalah faktor yang mempengaruhui prilaku ibu yang tidak menyusui bayinya meliputi Rasa sakit/nyeri pada payudara, Puting susu pecah, Merasa lelah, Asi tidak keluar, dan Takut gerak/ takut jahitan lepas. Populasi dalam penelitian ini adalah seluruh ibu Post SC, sampelnya adalah ibu post SC yang memenuhi kriteria inklusi yaitu ibu post SC, jumlah paritas tidak risiko tinggi, tidak ada penyakit penyerta, dapat baca tulis dan bersedia menjadi responden dengan tekhnik pengambilan sampel secara total sampling atau sampel jenuh sejumlah 30 ibu post SC. Data Penelitian ini diambil pada bulan Februari - Maret tahun 2018 di Ruang Mawar RSUD.Dr.H. Soewondo Kendal. Untuk analisis datanya menggunakan Chisquare.

\section{HASIL DAN PEMBAHASAN}

a. Karakteristik responden

Responden pada penelitian ini berusia $<35$ tahu $(60 \%)$, pendidikan SMP sebanyak $(40 \%)$ dan pekerjaan responden ibu rumah tangga $(86,7 \%)$. Hal ini akan mempengaruhi seseorang dalam menerima informasi dan akan mempengaruhi prilaku responden untuk menyusui bayinya.

Tabel 1.1 Distribusi kerakteristik responden.

\begin{tabular}{cccc}
\hline Karakteristik & Kategori & $\Sigma$ & $\%$ \\
\hline pendidikan & PT & 5 & 16,7 \\
& SMA & 11 & 36.6 \\
& SMP & 12 & 40 \\
pekerjaan & SD & 2 & 6,7 \\
& IRT & 26 & 86.7 \\
& PNS & 2 & 6.7 \\
& Wiraswasta & 2 & 6.7 \\
& $>40$ tahun & 0 & 0 \\
& 35-40 tahun & 12 & 40 \\
& $<35$ tahun & 18 & 60 \\
\hline
\end{tabular}

b. Hubungan faktor ibu menyusui dengan prilaku menyusui

\begin{tabular}{cccc}
\hline \multirow{2}{*}{ Faktor } & \multicolumn{2}{c}{ Prilaku Menyusui } & P \\
\cline { 2 - 4 } & segera & $\begin{array}{r}\mathbf{2 - 3} \text { hari } \\
\text { post SC }\end{array}$ & Value \\
\hline $\begin{array}{c}\text { nyeri pada } \\
\text { payudara }\end{array}$ & $2(33.3 \%)$ & $4(66.7 \%)$ & 0.019 \\
$\begin{array}{c}\text { Puting susu } \\
\text { pecah }\end{array}$ & $3(75 \%)$ & $1(25 \%)$ & \\
\hline
\end{tabular}

\begin{tabular}{ccc}
\hline Merasa lelah & $1(50 \%)$ & $1(50 \%)$ \\
$\begin{array}{c}\text { Asi tidak } \\
\text { keluar }\end{array}$ & $1(33.3 \%)$ & $2(66.7 \%)$ \\
Takut gerak/ & $0(0 \%)$ & $\begin{array}{c}15 \\
(100 \%)\end{array}$ \\
\hline
\end{tabular}

Dari tabel 1.2 faktor yang paling dominan yang dapat mempengaruhi prilaku menyusui pada ibu Post Sc adalah ibu takut gerak atau takut jahitannya lepas. Berdasarkan uji chi square $P$ value $=0,019$ ( $P$ value $<0,05$ ) yang maknanya ada hubungan antara faktor - faktor (rasa sakit/nyeri payudara, puting susu pecah, merasa lelah, ASI tidak keluar dan takut gerak/takut jahitan lepas) dengan prilaku inu post partum SC.

Proses persalinan merupakan proses yang memerlukan banyak persiapan terutama persalinannya dilakukan dengan metode Sectio Cesarea, ibu post SCsering tidak memenuhi perannya sebagai seorang ibu yaitu mempunyai kewajiban untuk meyusui bayinya yang disebabkan karena kondisi ibu yang lemah, dan nyeri post SC dan mobilisasi mempengaruhi pengeluaran ASI serta rasa cemas merupakan faktor yang paling banyak dialami oleh ibu post SC dalam mempengaruhi keberhasilan Ininsiasi menyusui dini.(Achadyah \& Sestu Retno DA, 2017; Hanifa \& Mufdlilah, 2015) dan dari penelitian - penelitian diberbagai negara menunjukkan bahwa persalinan dengan metode SC mempunyai efek untuk terhadap pemberian Inisiasi Menyusui Dini (IMD) yang akan mengakibatkan mengakibatkan penurunan angka IMD dan mempengaruhi penurunan menyusui di tiga hari pertama kelahiran, terutama ketika bayi masih dirawat di rumah sakit, dan akan berlanjut pada harihari berikutnya.(Februanti, Hartono, \& Kartilah, 2019)

Ibu Post SC sebagaian besar takut untuk melakukan mobilisasi dini yang dipengaruhi oleh rasa nyeri disekitar jahitan dan rasa takut jahitannya lepas merupakan faktor yang mempengaruhi keterlambatan pengeluaran ASI(Taek, 2018) dan faktor tersebut juga dipengaruhi oleh karakteristik responden yaitu dari pekerjaan ibu yang ratarata lbu rumah tangga yang kesulitan dalam memperoleh informasi dan pendidikan ibu yang sebagian besarberpendidikan sekolah menengah juga akan mempengaruhi seseorang dalam memberikan ASI pada bayi. maka diperlukan kerjasama dari semua pihat baik dari petugas kesehatan maupun dukunan dari keluarga hal ini sesuai dengan hasil 
penelitian bahwa dukungan suami dan petugas kesehtan mempengaruhi keberhasilan pemberian ASI secara dini pada ibu post SC.(Rompis, Tumurang, \& Raule, 2018) jadi diperlukan sebuah persiapan yang matang dan dukungan secara psikologis terhadap ibu Post SC dalam prilaku menyusui sacara dini.

\section{KESIMPULAN DAN SARAN}

dari penelitian ini dapat ditarik kesimpulan bahwa faktor rasa sakit/nyeri payudara, puting susu pecah, merasa lelah, ASI tidak keluar dan takut gerak/takut jahitan lepas merupakan faktor yang mepunyai hubungan terhadap prilaku ibu Post SC dalam memberikan ASI secara dini pada bayinya dan faktor takut gerak atau taut jahitan lepas merupakan faktor yang paling dominan yang memepengaruhi ibu post SC.

Dari penelitian ini diperlukan penelitian lanjutan yang lebih mendalam tentang ketidakberhasilan ibu post SC dalam melakukan inisisasi menyusui dini.

\section{DAFTAR PUSTAKA}

Achadyah, R. K., \& Sestu Retno Da, M. (2017). Hubungan Kecemasan Dengan Pelaksanaan Inisiasi Menyusu Dini (Imd) Pada lbu Post Sectio Caesarea (Sc) Di Ruang Edelweis Rsud Jombang. Jurnal Bidan, 3(2), 3037.

Asia, I. (International Baby Food Action Network Asia Unnual Report 2010). 2010. From Http:/Www.Worldbreastfeedingtrends. Org/Report/South_Asia_Report.Pdf

Desmawati, D. (2013). Penentu Kecepatan Pengeluaran Air Susu Ibu Setelah Sectio Caesarea. Kesmas: National Public Health Journal, 7(8), 360-364.

Februanti, S., Hartono, D., \& Kartilah, T. (2019). Relationship Between Post Sectio Caesarea Characteristics With Exclusive Breastmilk Giving In Tasikmalaya Indonesia. Paper Presented At The 1st International Conference On Inter-Professional Health Collaboration (Icihc 2018).

Hanifa, F., \& Mufdlilah, M. (2015). FaktorFaktor Yang Berhubungan Dengan Pengeluaran Air Susu Ibu Setelah Tindakan Sectio Caesarea Di Rs Pku Muhammadiyah Yogyakarta Tahun 2015. Stikes'aisyiyah Yogyakarta.
Kause, M. N., Trisetiyaningsih, Y., \& Sukmawati, A. S. (2016). Onset Pengeluaran Kolostrum Pada Ibu Post Partum Dengan Persalinan Normalvlebih Cepat Daripadavpersalinan Sectio Caesaria. Media IImu Kesehatan, 5(3), 193-199.

No.33, P. R. (2012). Peraturan Pemerintahrepublik Indonesianomor33 Tahun2012tentangpemberian Air Susu Ibu Eksklusif. From Http://Www.Hukor.Depkes.Go.Id/Uploa ds/Produk_Hukum/Pp\%20no.\%2033\% 20ttg\%20pemberian\%20asi\%20eksklu sif.Pdf

Ri, B. P. D. P. K. K. (2013). Riskesdas 2013. From

Http://Www.Depkes.Go.Id/Resources/ Download/General/Hasil\%20riskesdas \%202013.Pdf

Rompis, O., Tumurang, M. N., \& Raule, J. H. (2018). Faktor-Faktor Yang Berhubungan Dengan Inisiasi Menyusui Dini Di Rumah Sakit Siloam Manado. Paradigma, 1(5).

Taek, A. D. (2018). Survey Pelaksanaan Mobilisasi Dini Pada Ibu Post Sectio Caesarea Di Rsud Prof. Dr. Wz Johannes Kupang. Chmk Midwifery Scientific Journal, 1(2), 28-28. 